Adrien Guyot

\title{
The Shared Dream of the Americas: An Introduction to Americanity
}

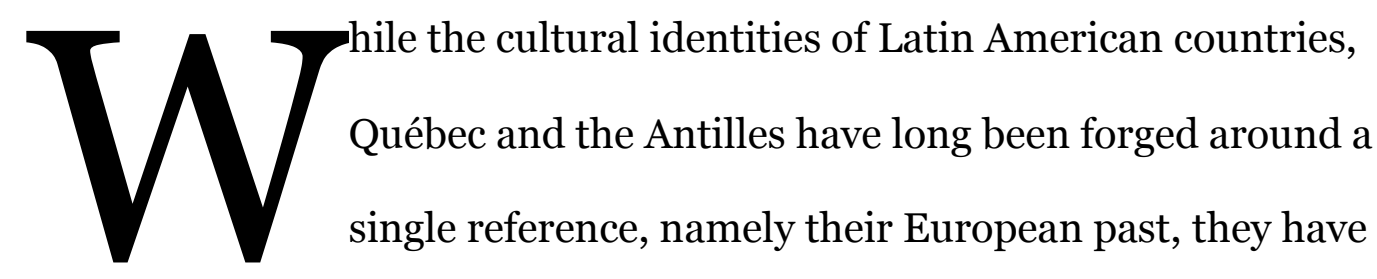
been recently showing signs of rupture and

heterogeneity. Thinkers from Québec (Sherry Simon, Pierre Nepveu, Gérard Bouchard), the Antilles (Édouard Glissant, Patrick Chamoiseau, Raphaël Confiant) or Brazil (Zilá Bernd) have been revisiting the concepts of origin and space from a completely different perspective. No longer would Europe be the anchor of their cultural identity; the roots and origins of their respective identity construction would have to be found elsewhere, in a new environment perhaps, embracing the modernity and diversity that are celebrated in the concepts of hybridity, transculturalism, creolization, which all slowly lead to a mythical crossroads: America. However, the establishment of a symbolic relation with the American territory remains somewhat problematic as the concept of Americanity relies on diverse discourses, which can be contradictory at times. The present study aims to shed light on the trendy concept that Americanity has become. On the one hand, I will point out the ambiguity that surrounds the 
concept, and on the other hand, I will briefly explain how the different perspectives in the reappropriation of the American space could lead to the establishment of America as a shared elsewhere. Concurrently, one may wonder: why is it still relevant to delve into the concept of Americanity today, and are the regional variants of the concept shaping a new map of the continent, or are they diluting the usefulness of Americanity altogether?

Evoking Americanity in an Anglophone context certainly raises eyebrows. Many scholars, unfamiliar with the concept, would actually argue that the term does not even exist. While such claim may seem rude, it is not completely erroneous. Very few studies indeed refer to Americanity as a concept. PanAmericanism and Americanness, however, are often used but one could definitely argue that they do not carry the same subversive power as américanité, americanidad or americanidade. The use of the term Americanity thus proves problematic. How could one attest to the validity of a concept relying on a term that does not exist? I would argue that the untranslatability of the concept is one of its strengths. It underlines its peripheral perspective, its novelty and raises questions about its nature in absentia in English. While it could be said that Americanity has been around since the $19^{\text {th }}$ century - in its Latin American variant - the concept re-emerged in the 1970s during a period marked by a series of interrogations concerning the notion of culture. 


\section{Revisiting the concept of culture in the $1970 \mathrm{~s}$}

The 1970s saw the emergence of a long series of debates revolving around the notion of cultural identity. Sherry Simon and Pierre L'Hérault for Quebec or Joubert Satyre for the Antilles, in particular, studied the context in which the concept of culture was revisited. The 1970 proved to be an era of sociodemographic mutations. Postcolonial migrations, the modernization of communications and transportations, the internationalization of mass culture as well as the great influence of feminism led to profound conceptual changes regarding the notions of culture and difference.

With all these claims and evolutions came a great variety of theories feeding an already extensive academic discussion. Hybridity is praised, left and right, as the future of any culture, of any language in contact with others. Against isolation or the ambition for purity sought after by atavistic cultures, hybridization, in all its epic glory, promotes new values, adventure, and encounters. As a result, hybridity, transculturalism, creolization make their appearance on stage and choose America as a common ground, the very same America that is defined by all theorists of Americanity, from Alejo Carpentier to Carlos Fuentes, from Fernando Ortiz to Édouard Glissant, as the land of all crossings, whether they may be cultural or biological. 


\section{Ambiguity}

If the concept of Americanity raises questions regarding its actual meaning, it is in part due to the fact that the term "America" remains somewhat hard to grasp. Many dictionaries will point out that it is imprecise, usually referring to North America or the United States. Many scholars have studied the question (Laroche 1992, Bernd 2002), which, as simple as it may be, proves more important than it seems. Arguably, the ambiguity would come from the fact that inhabitants of Latin-American countries refer to themselves as being Argentinians, Colombians and so on, while citizens of the United States do not refer to themselves as such, but as Americans. This little "confusion", as one may interpret it, is far more vexing than expected. Not only does it reveal much in terms of relations of power, but it also alters the vocabulary related to America in its entirety. In an attempt to clarify, one could say that:

- Americanized refers to the resemblance with the United States.

- Americanization refers to the act or the will of becoming American in many ways and assimilating the values and lifestyle of United States citizens.

- Americanness, sometimes mixed up with Americanity, still refers to the qualities and specificities found in the US, but goes beyond the border of the country to include the continent as a whole.

- Americanity, one could argue, differs from the latter due to its strong subversive connotation. It invites the cursed, the pariahs, and the 
minorities, to seize their right to rediscover together America, their continent, reinventing, reestablishing their link with the New World. Americanity, with its emphasis on rootless existence and cultural nomadism and its celebration of newness and hybridization, appears as a utopian Pan-American project of modernity. As a translation from americanité or americanidad, Americanity, which is not to be found in dictionaries, offers by its neologistic nature what Zilá Bernd would call an “opposition to the globalizing consensus imposed by English" (qtd. in Charron and von Flotow 124) dictated by the very country that usurped the name of a whole continent.

\section{Americanity or Americanities?}

One of the many interrogations raised by the use of Americanity as a concept comes from its questionable suitability as a universal translation for americanidad, américanité, and americanidade. Would it be deemed realistic to try and combine three different takes on the quest for continental cultural identity, considering the great cultural and economic diversity of the Americas? Bernd invites us to think:

Comment s'identifier à quelque chose qui a tant de facettes où se côtoient la richesse et la pauvreté, où les écarts sociaux et économiques sont 
immenses et où tant de cultures se sont entremêlées dans différents moments de leur histoire? (2002:10) ${ }^{12}$

Yet, the heterogeneity of the Americas is both an obstacle and a catalyst for the development of continental identity. As Marcio de Oliveira Bahia suggests, "what motiva tes those who have tried to construct an American cultural identity is exactly the desire of effacing these differences" (3). The use of Americanity as a concept should not however efface the differences among the variants of which it is composed. While they share the same backbone, these variants emerged indeed at different times and under different circumstances. Bernd and Bouchard, amongst others, have studied the transfers of the concept, noting that studies revolving around the construction of a concept first appeared in the first half of the twentieth century in Hispanic America following a long tradition of reflections on continental cultural identity (Domingo Sarmiento, José Marti, José Lezama Lima, etc.). In the 1970s, the term americanité started to be used to express a paradigm shift in the literary scene of Quebec. By the 1980 s and 1990s, the concept had reached the front stage of the intellectual debates, supported by literary works from Jacques Godbout (Une histoire américaine, 1986) or Jacques Poulin (Volkswagen Blues, 1984). The 1990s also saw the emergence of the term americanidade in Brazil, especially within the walls of the comparative literature field where researchers such as Núbia Hanciau, Zilá

\footnotetext{
1 "How could one relate to something with so many different facets, where wealth and poverty live side by side, where social and economic disparities are enormous and where so many different cultures have been interwoven at different times of their respective history?"

${ }^{2}$ All quotes translated from French by the author.
} 
Bernd or Euridice Figueiredo began to see links between American francophone literatures (Quebec, Martinique, Guadeloupe, Haiti) and Brazilian literary trends.

\section{Americanidad}

Many theorists and historians, among them Ricardo Avila, agree on the fact that the concept of americanidad had long been in the collective imaginary before it became a founding myth. Thus, when renowned Cuban intellectual Lezama Lima gave a series of lectures in 1957 - on which he would base the fundamental La expresión Americana - many Hispanic American intellectuals, including Sarmiento, Martí, Bilbao, Ortiz, Reyes, Salas and Carpentier, to name a few, had already tried to answer a great number of questions regarding the American identity. Their contributions, whose perspectives and directions sometimes greatly varied, provided a set of theories and reflections about the American continent that Hispanic American scholars would refer to as americanidad. In other words, the thinkers aforementioned, did not attempt to elaborate a concept per se, but their joined participation in the debates revolving around continental identity developed into a discourse of continental union and resistance towards European domination, which would be embodied by the concept of americanidad.

One of the most emblematic reactions against Eurocentrism came with Alejo Carpentier's notion of real maravilloso, which will set one of the most prevalent 
aesthetic features of Americanity. Influenced by the French Surrealists, and in particular André Breton, Carpentier developed his concept of the marvelous through a hyper-valorization of the American fantastic which feeds on the new,

the real, the natural and the presence of the hybrid, the baroque, and the métis:

Because of the virginity of the land, our upbringing, our ontology, the Faustian presence of the Indian and the black man, the revelation of its recent discovery of its fecund racial mixing [mestizaje], America is far from using up its wealth of mythologies. (88)

Beside the strong aversion towards Eurocentrism, the concept of americanidad evolved to take into consideration the growing imperialism of the United States. As Avila (1998) suggests, the concept in Hispanic America added a new facet to its already complex shape as the United States displayed some of the features of a colonizing empire. North America disappeared altogether from the concept of americanidad, which reinforced its peripheral nature around the idea of "Nuestra América" first articulated by José Martí in 1891. This evolution-characterized by a division south of the Rio Grande - leading to the emergence of a purely Hispanic American americanidad could explain the need for a different variant up north, rather than a sheer transfer of concept in Quebec where américanité re-emerged in a different form in the 1970 .

\section{Américanité : Quebec}

Quebec distinguished itself during the nineteenth and twentieth centuries by a strong attitude of preservation, which was characterized, amongst other things, by cultural isolationism. The 1970 s were marked by a series of 
immigration waves, which greatly influenced the sociocultural landscape of the province and led to the emergence of a francophonie métissée in Quebec. Traditionally clinging on to its European heritage, Quebec started to embrace its diversity and attempted to redefine its point of origin through the concept of americanité. According to writer and historian Gérard Bouchard (2000), américanité established itself as a concept of resistance against Eurocentrism, asserting the relationship between the Québécois and the American continent. However, while the principal objective was initially to rethink and redefine the relationship of dependence with France, américanité quickly developed into a multi-faceted concept. Indeed, while for some the neologism refers to the former French America and its immense cultural heritage; for others it would emerge from an indigenous conception in which the transcultural Québécois would find his roots in pre-Columbian history. Bouchard, an ardent defender of the concept, sees in américanité the marks that popular culture and language acquire as they distance themselves from the norms of purity observed in the language of the French hexagon. As a result, Quebecois literature will only emerge when its culture becomes truly American; that is, filled with neologisms, impurities, Anglicisms and transgressions associated with the rediscovery of America.

As américanité developed into a Pan-American utopia, making the continent the land of all crossings, glorifying heterogeneity and diversity through novels like Volkswagen Blues (1984) by Jacques Poulin or Les têtes à Papineau (1981) by Jacques Godbout, the concept met strong detractors, such as Jean Morisset or Pierre Nepveu who quickly pointed out its ever-growing ambiguity: 
Un néologisme québécois qui a trop souvent signifié (et signifie de moins en moins) une immense ignorance de l'Amérique et sa réduction à des valeurs stéréotypées en lesquelles je ne me reconnais guère : primitivisme, naturalisme, anti-intellectualisme, mythologie des grands espaces, sacralisation de la jeunesse et du tout-neuf. (7) 3

The most vigorous critique came, however, from Joseph Yvon Thériault, who attacked Yvan Lamonde's promotion of américanité over américanisation ( $\mathrm{Ni}$ avec eux ni sans eux, 1996). While the first term refers to a set of positive phenomena regarding the creation of a discourse of mobility, inclusiveness, and openness in the new world, the second one evokes the alienating cultural imposition of a US model on Quebec. Thériault saw much confusion in Lamonde's attempt to empower the concept of américanité-which should include Latin America-considering the novels that served as its backbone (such as Volkswagen Blues or Une histoire américaine) solely interrogated the Quebec-United States relationship. Thus, there seemed to be a discrepancy between intent and implementation in Lamonde's acclaimed work, which inspired Thériault:

L'américanité est un concept-poubelle. Poubelle dans le sens d'un ramassis hétéroclite d'énoncés dont on réussit difficilement à trouver la forme. Poubelle aussi dans le sens d'un concept qu'il faut rejeter, car

\footnotetext{
3 "A Quebecois neologism that reveals [...] a profound ignorance of America and its reduction to stereotypical values [...]: primitivism, naturalism, anti-intellectualism, mythology of wide open spaces, sacralization of youth and newness".
} 
inutile sinon dangereux, pour comprendre le parcours historique de la nation française d'Amérique. (2002: 23) 4

Despite Thériault's harsh words, Lamonde's influence is not to be discarded. Besides, one could argue that the ambiguity, despised by Thériault, is specifically what makes américanité so intriguing on both a theoretical and empirical level. It reveals that while americanidad evolved to exclude completely the United States, the discourses on américanité, as inclusive of the continent as they may be, revolve above all, around the dynamics of attraction and repulsion towards the United States, which is a result of a historic ambivalent fascination and fear of américanisation. 5

\section{Américanité - Caribbean}

To evoke the Caribbean as a part of America seems at first sight more complicated than to understand the integration of Quebec into the continent. Yet, as Joubert Satyre (2009) explains, despite their geographic and linguistic isolation, the literatures of Haiti, Guadeloupe and Martinique are often studied within the scope of American literatures. Thinking about the américanité of these Caribbean islands would not seem geographically challenging, considering

\footnotetext{
4 "Americanity is a rubbish concept. Rubbish in the sense of a shapeless patchwork of heterogeneous utterances. Rubbish also because it should be rejected, as it is a useless if not dangerous way of interpreting the historical development of the French nation of America

5 These dynamics are not only tied to the concept of Americanity, but also to the concept of continental cultural transfers. Michel Nareau's study of baseball as an American founding myth and its propagation in the continent and Jean Morency's work on the continental origins, derivations and recuperations of the literary myth of Evangeline (poem by American writer Henry Wadsworth Longfellow) should not be overlooked.
} 
that it would merely be a transfer from the continent to which they have always been arbitrarily attached: Europe. Yet, it would be preposterous to suggest that américanité took Haiti, Martinique and Guadeloupe by storm. Indeed, Caribbean thinkers have not been so concerned with questions of Americanity. Is it due to the ambiguity surrounding the concept in Quebec? Not quite. While américanité in the Caribbean is a fairly recent concept, it is somewhat related to other concepts like africanité, antillanité and créolité, which also emerged from a need to break away from the cultural imperialism of Europe. Thus, if we were to retrace the history of the development of these concepts, we would note that américanité in this region was more of a stepping-stone to antillanité and créolité than a concept in itself.

In the 1960 s Édouard Glissant began to build the foundations of his concept of antillanité after he noted, throughout a long series of essays, that the Antillean society was ill, due to successful colonization measures. He undertook the project of rebuilding the Antillean collective identity. As a result, antillanité emerged as the willingness to reinforce collective memory and stand as far as possible from the tutelage of France. In Le Discours Antillais (1981) Glissant went as a far as to question the arbitrary attachment of the Antilles to Europe and called for the reappropriation of the archipelagic and continental components of the Caribbean territory and their inclusion in the American sphere. Celebrating newness, just like the theorists of americanidad, Glissant proposed the notion of créolisation to define the dynamics of globalization and hybridization found not only on the American continent, but well beyond, in the “Tout-Monde". While Glissant's theories proved to be extremely influential - 
more so in America than in Europe - antillanité did not flourish as a literary movement, contrary to the concept of créolité founded by Patrick Chamoiseau, Raphaël Confiant and Jean Bernabé at the end of the 1980s. Advocating the use of Créole as a language in artistic production in order to offer "une expression plus juste ... une esthétique plus vraie" (Éloge de la Créolité, 13), the concept emerged as a variant of américanité, which the three authors nevertheless criticized for being "un bloc à vocation hégémonique" (56), incapable of reflecting the specificity of the Caribbean.

Despite receiving praise in Martinique, Guadeloupe and France, one could argue that the concept of créolité failed to convince all the French Caribbean islands, starting with the largest Creole-speaking country in the world, Haiti. If Haitian authors did not embrace créolité-beyond the fact that Creole, as everyone's first language, does not carry any subversive connotation in the country-it is in part due to the particular situation of Haiti. Guadeloupeans and Martinicans became aware of américanité through the concept of antillanité. For Haiti, the fracture and independence of 1804 tempered the double nostalgia Europe/Africa. As early as 1927, Normil Sylvain suggested closer ties between Hispanic America and French America by focusing on Amerindians (Caribs and Arawaks) who pre-existed the arrival of the conquistadors.

Haiti also displayed major differences with Guadeloupe and Martinique because of its large diaspora, disseminated for the most part in North America. As a result, many Haitian writers, such as Émile Ollivier (Passages, 1991; Repérages, 2001), Edwige Danticat (Krik? Krak!, 1996), Dany Laferrière (Pays 
sans chapeau, 2006 Je suis un écrivain japonais, 2008, L'Énigme du retour, 2009) or Marie-Célie Agnant (Alexis d'Haïti, 1999, Le Livre d'Emma, 2001 La Dot de Sara, 200o) are more concerned with topics of memory, exile, placelessness, than with questions of language and identity, which are posited differently. In "Ce livre est déjà écrit en anglais, seuls les mots sont en français", Dany Laferrière commented:

Mon combat ne se faisait plus avec la France. J'avais réglé le cas de la France d'une manière inusitée, en lui faisant affronter un monstre plus fort que lui, l'Amérique. Comment? Et bien, j'avais découvert par hasard que je vivais en Amérique, qu'Haïti était en Amérique et non en Europe. ${ }^{6}$

Thus, twenty-five years after the establishment of the concept, créolité which differs from américanité by its stronger postcolonial attitude as well as its emphasis on insularity, natural frontiers and most importantly a dogmatic and totalitarian approach to artistic production - is threatened by a return to américanité. Indeed, with a growing number of Caribbean writers producing texts from Canada or the United States, and the current focus on Vincent Placoly's defense of the concept, américanité has made its comeback, drawing links between the Caribbean and the continent as well as portraying the migrant Caribbean subject, with his or her double state of minority, in his or her adaptation to the reality of the new continent.

\footnotetext{
6 "My battle with France was over. I had dealt with France in an uncommon way, by making it face a stronger monster, America. How? Well, I had found out by chance that I was living in America, that Haiti was in America and not in Europe".
} 


\section{Americanidade}

While America, as a continent, has long been a topic of interest for Brazilian authors and intellectuals, with important works such as Iracema (1865) by José de Alencar displaying one of the first attempts at reappropriating the toponym “America”, Americanity's latest variant, americanidade, was only developed in the 1990 s in Brazilian academia. The concept began to circulate within the ranks of French literary studies where research was until then strictly limited to France. A new focus on establishing a link between francophone cultures of America (Martinique, Guadeloupe, Haiti, and Quebec) and Brazilian trends led to the construction of americanidade in 1995 with the release of Literatura $e$ americanidade, co-authored by Zilá Bernd, Maria do Carmo Campos and Wladimir Krysinski. Highly influenced by francophone intellectuals such as Maximilien Laroche, Dany Laferrière, Edouard Glissant, and Gérard Bouchard, to name a few, Bernd helped develop the concept by combining traits from americanité and americanidad. As a result, while advocating an Americanity that would encompass the entire continent, she established in "Américanité: les transferts du concept" (2002) a concept revolving around the absence of the United States. By citing Laroche's work on the appropriation of the toponym "America" by the U.S., and calling for the reappropriation of the term and continent by peripheral poles, Bernd designed americanidade in its most utopian and modern iteration. 


\section{America: a Shared Elsewhere?}

The question that arises is whether these different stances on Americanity may result in the establishment of a healthy concept. In other words, can these different perspectives cohabitate?

Besides a similar glorification of America, the continent of the new and the hybrid, americanidad, américanité and americanidade have in common a very particular relationship with the United States. While américanité has been designed against yet always around this relationship, the other variants are altogether excluding the almighty United States. The lack of an equivalent in English for the concept7 which could be equated to its nonexistence in the United States or Anglophone Canada, can help visualize a mapping of the different variants of Americanity in which the centre would be empty. This emptiness can however be filled with the respective collective imaginary of the different regional variants and create a shared elsewhere, a common space of otherness, a heterotopia.

In a series of lectures given in 1967, Michel Foucault developed the concept of heterotopia after examining other spaces. The French intellectual saw in

\footnotetext{
7 So far, there has been very little mention of Americanity, except perhaps by Anibal Quijano and Immanuel Wallerstein, "Americanity as a concept, or the Americas in the modern world system"(1992). The nonexistence of the concept in English should not however mask the contributions of David Saldivar, Walter Mignolo or Winfried Siemerling, whose works on continental identities and transnational practices are remarkable.
} 
Utopias sites with no real space; sites that present society in a perfected form but fundamentally set in an unreal space. Heterotopia, on the other end, designates a kind of effectively enacted utopia set outside of all places it represents, but whose location could be indicated in reality. Foucault sees in the analogy of the mirror a joint experience between utopia and heterotopia. The mirror is a utopia in the sense that it is a placeless place. In the mirror, the subject can see himself or herself where he or she is not, in an unreal space that opens up behind the glass. The mirror is also a heterotopia since it exists in reality and projects a reflection of the subject, making the place occupied at the moment of the gaze both real and unreal since in order to be perceived, it has to pass through a virtual point: the space beyond the glass. The heterotopia is capable of juxtaposing, in a single real space, several places or sites that are in themselves incompatible. Thus, if we were to use Foucault's analogy of the mirror, we could imagine a situation where several subjects would be standing in different places, in front of a multifaceted mirror whose reflections would contain all the subjects. With our mapping of the diverse regional variants of Americanity, America would be such a mirror.

\section{From Heterotopia to Heterodystopia}

Americanity is catchy and trendy. As a concept, it has been extensively praised. However, there seems to be a gap between theory and its application in novels for example. Numerous texts, - especially those written after the September 11, 2001 events, - show great difficulty in carrying the same 
enthusiasm. A large number of francophone literary texts deal indeed with memory conflicts, monstrosity and infanticide, showcasing America as the land of lost opportunities, broken dreams, a land with a troubled past and no future: what one might call a heterodystopia.

While the heterotopic nature of America can be explained on a theoretical level by the reappropriation of the continent by cultural minorities - which, as this analysis suggests, would be linguistic minorities as well - it could also be linked, as a quick empirical study of novels would point out, to the literary subject of Americanity: the other.

The relationship between personal and collective identity as well as the perception of the other have been two of the most prevalent components of contemporary discourses on literature and culture. Jean-François Lyotard (1979), amongst others, defines otherness as one of the key concepts of postmodernity.

Otherness has been one of the most important themes of the Quebecois literature since its birth, present in Les Anciens Canadiens (1863) by Philipe Aubert de Gaspé. With novels such as Volkswagen Blues, quoted a lot by the defenders of americanité, the other - embodied by Pitsémine, a young metis woman who accompanies the protagonist on a road trip to find his brother-is profoundly celebrate:

Vous dites que vous êtes "quelque chose entre les deux" ...Eh bien, je ne suis pas du tout de votre avis. Je trouve que vous êtes quelque chose de 
neuf, quelque chose qui commence. Vous êtes quelque chose qui ne s'est encore jamais vu. $(224)^{8}$

This speech, pronounced by the main character, Jack Waterman, attempting to reassure his partner, could be seen as a metaphor of the euphoric contemporary discourse on américanité. Yet, it is the reason for this statement that is most interesting. Pitsémine's otherness and hybridity, while celebrated by Jack, do not confer her any advantage in society. On the contrary, they are the cause of her exclusion: 9

Sa mère, en épousant un Blanc, avait perdu la maison qu'elle possédait sur la réserve de La Romaine ; elle avait été expulsée et elle avait perdu son statut d'Indienne. Mais les Blancs, de leur côté, la considéraient toujours comme une Indienne et ils avaient refusé de louer ou de vendre une maison aux nouveaux mariés. (97) ${ }^{10}$

As a result, Pitsémine is forced to wander aimlessly, In limbo, incapable of setting roots in the continent. Thériault, in one of his critiques of américanité ,

8“You say that you're 'something in between'...Well, I don't agree with you at all. I think you're something new, something that's beginning. You're something that has never been seen before". Translated by Sheila Fischman. Volkswagen Blues, Toronto: Cormorant Books, 2002, p.169.

9 This exclusion is quite symptomatic of the lack of importance given to the First Nations in the founding myths of the Americas. Jean-François Côté, in his defense of "le renouveau du grand récit des Amériques" (2001) advocates against the micro discourses of postmodernism and instead calls for the reestablishment of a great continental discourse which would involve the First Nations.

10 "She had been born in a trailer because when her mother married a white man she had lost her house on the reservation at La Romaine; she had been expelled and lost her Indian status. But whites still considered her an Indian, and they had refused to rent or sell a house to the newlyweds". Translated by Sheila Fischman. Volkswagen Blues, Toronto: Cormorant Books, 2002, p. 69. 
insists sarcastically on the relation between newness and wandering: "À l’idée de la nouveauté, il faut immédiatement ajouter celle de l'errance. Sans passé, ni mémoire, l'être de l'américanité est un être sans lieu" (2002:30).

While Thériault's analysis of américanité proves enlightening on many points, one could question the previous statement by interrogating the link between memory and Americanity. Indeed, many literary texts, which could be studied in light of the concept, are deeply rooted in issues of memory and heritage.

If Pitsémine's journey differs from Jack's quest, it is mostly because she revisits the continent through a postcolonial perspective, proposing a revision of history as the couple drives across America, giving legitimacy to unknown Indian legends and forgotten tales of settlement. Thus, her continental wanderings offer a certain degree of satisfaction, in a very peculiar postmodern way.

Marie-Célie Agnant, Haitian-born writer from Quebec, proposes a much more sombre take on the weight of memory when settling in America. In Le Livre d'Emma (2001), the eponym protagonist from Haiti, locked up in an asylum in Montréal after committing an infanticide, is incapable of escaping the determinism of memory that she sees as a malediction: 
Cette malédiction venue des cales des négriers est telle que le ventre même qui nous a porté peut nous écraser. Et la chair de ta propre chair se transforme en bête à crocs et, de l'intérieur, déjà te mange. (162) ${ }^{11}$

Emma's insanity lies, amongst other things, in her inability to reconcile pays rêvé and pays réel ${ }^{12}$. America, which could have been her heterotopia, quickly turns out to be dystopian. While Poulin's Pitsémine succeeds, to some extent, in recolonizing a space that was torn from the First Nations, Emma transposes onto her new environment a history of suffering and trauma linked to the Duvalier dictature. Her failure to adapt not only questions the virtues of transculturalism, but also the habitability of the territory as a whole. Quickly, the American dream is reduced to the "trottoirs gelés de l'Amérique" (13).

\section{Post September 11 Americanity}

The implacable determinism of Emma's lineage finds a parallel in Nicolas Dickner's Tarmac (2009) or in Catherine Mavrikakis' Le Ciel de Bay City (2008) who both share a similar tone of impending doom. While Hope Randall, the protagonist of Tarmac, inherited a vision of the end of the world, like the rest of her family, Amy Duchesnay, the main character of Le Ciel de Bay City, is haunted by the holocaust that will eventually lead her to set her house on fire

\footnotetext{
11 "That curse from the holds of the slave ships is such that the very womb that carried us can crush us. And the flesh of your own flesh transforms itself into a fanged beast and eats you up from within.” Translated by Zilpha Ellis, The Book of Emma, Toronto: Insomniac Press, 2006, p. 199.

${ }^{12}$ Pays rêvé and pays réel are two terms frequently used by Caribbean thinkers, amongst whom Glissant and Laferrière, to designate the difference between nostalgia, imagination and reality.
} 
and kill her family on July 4, which coincides with her birthday as well as Independence day.

Thériault insists that the September 11 events sealed the end of the concept of Americanity. He points out that the theological and political decision of retaliation created a profound malaise in Quebec, for example, whose general opinion aligned once again with Europe's. I would argue otherwise, stating that September 11 marks indeed a shift but in a different direction. Tarmac and Le Ciel de Bay City are not unique examples of a sense of catastrophe that became one of the most important themes of Quebecois and Caribbean literatures in the twenty-first century.

Annie Dulong considers September 11 to be so influential that it shaped her, not only as a writer, but also as an American:

Je suis née le 11 septembre 2001, le dos soudé à un futon orange, les pieds posés au sol pour me retenir de fuir. Je me suis éveillée devant les images diffusées à l'écran d'avions s'encastrant dans des tours. ${ }^{13}$

As a matter of fact, beyond theoretical or cultural discussions, the September 11 events - perhaps because of their spectacular choreography or the importance they were given in the media-had an impact on everyone, as suggested by the fact that everyone remembers what they were doing when they first heard about the attacks, as if it was almost personal, relatable.

${ }_{13}$ "I was born on September 11, 2001, my back stuck to an orange futon, my feet resting firmly on the floor to keep me from running away. I woke up in front of the images, on TV, of planes crashing into towers". 
The cultural reappropriation of the destruction of the twin towers, so American - in its United States terminology, has set Americanity on a different course. An American trauma, in all its violence and spectacular imagery, becoming the burden of a whole continent, is both an indicator of the Americanization of the continent as well as a sign of completion of the subversion enabled by the peripheral forces of Americanity.

\section{Beyond Americanity?}

Once euphoric, discourses on Americanity are now toned down. Beside the gap between theory and artistic production, the utopian take on the rediscovery of the continent was evidently going to meet detractors at some point. The recent literary manifestations of Americanity - at least in its francophone variants - present the American continent as a heterodystopia, constantly reinvented, without roots, with new generations building new foundations, in a perpetual loop. Consequently, it would be somewhat delicate to validate a concept where one could imagine the American subject doomed to wander aimlessly in limbo, dealing with identity issues that he or she would never be able to transcend. However, assessing the positivity of Americanity may prove completely irrelevant. Its interest lies in its actuality. As such, how could one not see the recent pessimism expressed in novels, the counter-discourses, the conflicts of memory and heritage, the broken dreams, the sense of catastrophe and ending as the most convincing traits yet of the settling difficulties encountered by the pioneers in the new world? 


\section{Works Cited}

Agnant, Marie-Célie. Le Livre d'Emma. Montréal: Remue-ménages, 2001. Print.

-------. The Book of Emma. Trans. Zilpha Ellis. Toronto: Insomniac Press, 2006. Print.

Alencar, José de. Iracema. New York: Montecristo Publishing, 1865 [2012]. Print.

Aubert de Gaspé, Phillipe. Les anciens Canadiens. Montréal : Fides, 1863 [1970]. Print.

Ávila, Ricardo. "Es posible una identidad americana en el contexto de la integración económica?” Continentalisation, Cahier de recherche, 98:5,

Nov. 1998. Print.

Bahia, Marcio de Oliveira. "The concepts "americanidad", "américanité" and "americanidade": peripheral perspectives". Ottawa: University of Ottawa, 2004. Web. 20 July 2014.

Bernabé, Jean. Fondal-Natal. Paris : L’Harmattan, 1983. Print.

Bernabé, Jean, Patrick Chamoiseau, and Raphaël Confiant. Éloge de la créolité. Paris: Gallimard, 1989. Print.

Bernd, Zilá. Américanité: mobilités transculturelles, Québec, Presses de l’Université Laval, 2009. Print.

---. “Américanité : transferts du concept". Da revista interfaces Brasil/Canada 2, 2002. Web. 14 July 2014.

Bouchard, Gérard. Genèse des nations et cultures du nouveau monde : Essai d'histoire comparée, Montréal : Boréal, 2000. Print.

Carpentier, Alejo. "Marvelous Real in America”. Magical Realism: Theory, History, Community. Trans. Tanya Huntington and Lois Parkinson Zamora. Durham, N.C.: Duke UP, 1995. Print 
Charron, Marc and Luise Von Flotow. "From Quebec to Brazil: Translation as a Fruitful Dialogue Between "Américanité" and "Americanidade"”. Cadernos de tradução 2. 30 (2012): 119-38. Web. 20 july 2014.

Côté, Jean-François. "Le renouveau du grand récit des Amériques: polyphonie de l'identité culturelle dans le contexte de la continentalisation". Le grand récit des Amériques. Sainte-Foy, Québec: Editions de l'IQRC, 2001. Print.

Danticat, Edwidge. Breath, Eyes, Memory. New York: Vintage, 1994. Print.

---. Krik ? Krak !. New York : Vintage, 1996. Print.

Dickner. Nicolas. Tarmac. Québec : Alto, 2009. Print.

Dulong, Annie. "L'écriture américaine”, La main, le souffle, 29 april 2010.

Web. 20 july 2014.

Glissant, Édouard. Le Discours antillais. Paris : Gallimard, 1981. Print.

-------. Tout-Monde. Paris : Gallimard, 1993. Print.

-------. Traité du Tout-Monde. Paris : Gallimard, 1997. Print.

Harel, Simon. Espaces en perdition, tomes 1 et 2, Québec, Les Presses de l'Université Laval, 2008 et 2009. Print.

-------. Les passages obligés de l'écriture migrante. Montréal: XYZ, 2005. Print.

--------. Le voleur de parcours. Montréal : XYZ, 1999. Print.

Laferrière, Dany. Pays sans chapeau. Montréal : Boréal. 2006 [1996]. Print.

----------. "Ce livre est déjà écrit en anglais, seuls les mots sont en français”, île en île, 2000. Web. 20 july 2014.

Lamonde, Yvan, “Américanité : inflation du mot, de la notion?”, Le Devoir 1 Oct. 2001: A6. Web. 20 july 2014.

Lamonde, Yvan. Ni avec eux ni sans eux. Le Québec et les États-Unis. Québec : Nuit Blanche Éditeur, 1996. Web. 20 july 2014. 
---------. “Pourquoi penser l'américanité du Québec?” Politique et sociétés 18 :1 (1999): 93-98. Web. 20 July 2014.

Laroche, Maximilien. "Américanité et Amérique” in Confluences littéraires : Brésil/Québec, les bases d'une comparaison, ed. Peterson, M. and Zila Bernd. Montréal : Balzac. 1992. 189-202. Print.

Lezama Lima, José. La expresión Americana. Mexico: Fondo de Cultura Económica, 1988. Print.

L’Hérault, Pierre. "Volkswagen blues : traverser les identités", Voix et Images 15.1 (1989): 28-42. Web. 20 July 2014.

Lyotard, Jean-François. La condition postmoderne : rapport sur le savoir. Paris : Minuit, 1979. Print.

Martí, José. "Nuestra América”. 1891. Ciudad Seva. Web. 20 July 2014.

Mavrikakis, Catherine. Le ciel de Bay City. Montréal: Héliotrope, 2008. Print.

Morency, Jean. Le mythe américain dans les fictions d'Amérique. De Washington Irving à Jacques Poulin. Québec : Nuit blanche, 1994. Print.

--------.. "Les tribulations d'un mythe littéraire américain: l'odyssée continentale d'Évangéline, poème de Longfellow”. Mythes et Sociétés des Amériques. Montréal: Québec Amérique, 2007. 350-367. Print.

Nareau, Michel. "Le mythe états-unien du Baseball et ses contradictions dans les Amériques". Mythes et Sociétés des Amériques. Montréal: Québec Amérique, 2007. 173-204. Print

Nepveu, Pierre. Intérieurs du Nouveau Monde. Montréal: Boréal, 1998. Print.

Ollivier, Émile. Passages. Montréal: L’Hexagone, 1991. Print.

----------. Repérages. Montréal: Leméac, 2001. Print.

Poulin, Jacques. Volkswagen Blues. Montréal : QA, 1984. Print. 
Quijano Anibal and Immanuel Wallerstein, "Americanity as a concept, or the Americas in the modern world system." International Social Science Journal 134, (1992): 549-557. Web. 19 July 2014.

Simon, Sherry et al. Fictions de liidentitaire au Québec. Montréal : XYZ, 1991. Print.

Satyre, Joubert. "La littérature antillaise : une littérature de l'Amérique". Québec français, 154 (2009): 86-89. Web. 14 July 2014.

Thériault, Joseph-Yvon, "L’américanité après le 11 septembre". In Mémoire et démocratie au Québec. Montréal : Québec Amérique, 2005. 375-386. Web. 19 july 2014.

. "L’Amérique et l'américanité ne peuvent être notre projet", Le Devoir 22 may 2001: A7. Web. 18 July 2014.

----------. “Chronique des Amériques : l'américanité comme effacement du sujet Québécois", Argument 3. 1, (2000-2001): 136-144. Web. 18 July 2014. -. Critique de l'américanité. Mémoire et démocratie au Québec. Montréal: QA. 2002. Print.

Adrien Guyot is a PhD candidate at the University of Alberta in the Modern Languages and Cultural Studies department. His research interests include dystopian narratives, monstrosity and américanité in French-Canadian and Caribbean literatures.

aguyot@ualberta.ca 